\title{
The English Teachers' Management for Genre-Based Writing Instruction in Learning Process of 2013 Curriculum at Senior High School
}

\author{
Yuni Cenrikawaty, Mukhaiyar, Anas Yasin, and Ngusman Abdul Manaf \\ Univeritas Negeri Padang \\ yunicenrikawaty1973@gmail.com
}

\begin{abstract}
This research aims to know how the English teachers' management for the teaching strategies in learning process of genre-based writing instruction in 2013 curriculum on Senior High School students of Pesisir Selatan. This research is limited to know how the English teachers manage the first stage building knowledge of field, modeling of text, joint construction of text and independent of construction text in learning process to help students learn English writing skill as suggested by genre-based writing instruction. The type of this research is a qualitative evaluation with ethnography method. The data are mostly gained from the classroom analysis done through observation supported by field notes and videotaping, interview and document analysis. The subjects of this research were English teachers from six senior high schools that had implemented the 2013 curriculum in Pesisir Selatan Regency. The result shows that most of English teachers hadn't manage the teaching strategies in learning process to help students learn English writing skill as suggested by genre-based writing instruction well. It was proved that there is a mismatch between the conceptual theories of genre based writing instruction and these teachers' teaching practice in the classroom, particularly in selecting appropriate classroom activities for each phase of the curriculum cycle. It was caused by limited to the teachers' knowledge and understanding to the implementation of genre - based instruction. Based on the data analysis, the researcher concludes that the learning process of genre-based writing instruction on Senior High School students in 2013 curriculum of Pesisir Selatan Regency has not been managed by the English teacher optimally.
\end{abstract}

Keywords-Writing skill; Genre-Based Writing Instruction

\section{INTRODUCTION}

Teaching writing to the senior high school students where English is a foreign language is not easy. Most of English teachers said that most of students faced some problems in writing; the students get poor performance in English writing. For example, it is difficult for students to express their ideas in written form as they often wrote it ungrammatically. In other word, the students often encounter difficulties in keeping up with their work, particularly in producing written work. Classroom teachers of newly enrolled the students note that these students have grammatical knowledge and developed reading skills and they are motivated to learn English. However, they lack confidence in their writing ability and are often reluctant to participate in writing activities or to submit written assignments. The difficulties include choosing appropriate vocabulary, organizing the structure properly depending on the topic or the purpose of writing, following correct grammar rules, and integrating ideas.

Writing as the most difficult skill had been stated previously by Richards and Renandya (2002). The context was for students in EFL (English is a Foreign Language). It is also believed that the students from native speakers" context found writing as difficult skill to be mastered.

To solve this problem, education policy for English language teaching in Indonesia has undergone several changes. The changing aims at improving the outcomes of English language teaching itself. It was proved that since 2004, 1994 curriculum was the changing to be competence based curriculum $(2004 \mathrm{CBC})$, then since $2006,2004 \mathrm{CBC}$ was the changing to be 2006 School- based curriculum. Next since 2013, 2006 curriculum was the changing to be 2013 curriculum.

So that since curriculum in 2006, the English language teaching in Indonesia education has started implementing an approach that is genre- based approach. Genre-based approach is an appropriate approach to teaching English, especially to teaching writing skill. It was caused by genre based approach based on the theories of language and theories of language learning. Theories of language as the base of the genre based approach are language as system and language as functional. There are three assumptions that underlay the genre based approach: (1) learning language is a social activity, (2) learning occurs more effectively if teachers are explicit about what is expected of students, (3) the process of learning language is a series of scaffold developmental steps which address different aspects of language. 
Teaching of English writing skill by applying the genre based approach means that the teaching learning activities focus on learning many kinds of text. Genre means many kinds taught to the senior high students in Indonesia. Those texts are: recount, report, discussion, explanation, exposition analytical, exposition hortatory, news item, anecdote, narrative, procedure, description and review. A text is a passage whether spoken or written that has unified meaning. A text is influenced by the context of culture and context of situation. It can be short or long, the principle is that the text has meaning, the text is aimed to whom, and what is the way the text is communicated, whether in spoken or written way.

More ever proponents such as Kay and Dudley- Evans (1998:310) have argued that the genre approach is more effective for learners to advance their writing skills in a second language than the process approach since the model helps free students from their severe worries over writing. For instance, at the University of Brunei Darussalam, Henry and Roseberry (1998: 154-155) did an experimental study in academic classes using short tourist information texts in English. Participants in this research were divided into two groups: a group which used the genre-based instructions and a group which did not employ the genre approach in the same writing task. After three weeks, participants took a test. The genre group did better than the non-genre group, and the data showed that knowledge of the typical structure of the content made it easier for learners to arrange their ideas in terms of both achieving their communicative goals and producing more well-organized writing. It proved that the learnerse understanding of both the rhetorical structure and the linguistic features was increased by the genre-based instructions.

It"s believed that genre - based instruction is appropriate approach to teaching writing skill on senior high school students, it was caused by as follow;

a. It is able to make students easier to generate numerous descriptions and explanations of discipline specific genre exemplars;

b. It is able to make students developing strategies and cultural tools that enable you to develop awareness and discipline - specific writing;

c. It still efforts let students to follow the process approach which help students to work through several stages of the writing process;

d. it focuses students on models and key features of text written for particular purpose

e. It is able to attempt students easier and quicker to produce the first draft through imitating the given genre;

f. It is able to decrease students"exhibited difficulties in expressing themselves in writing such as; choosing appropriate vocabulary, organizing the structure properly depending on the topic or the purpose of writing, following correct grammar rules, and integrating ideas;

g. It is able to make students producing meaningful passage;

h. It is able to activate students"ememories of prior writing experiences whenever encounter the task of creating a new piece in familiar genre

i. It is able to make students focus on familiarizing with the target text type or genre, and drawing attention to the possible contexts of situations in which the chosen text- types or genre may be used on building knowledge of field stages in the implementation of genre - based writing instruction model in writing class;

$\mathrm{j}$. It is able to make the students focus on the educational and social function of the genre analysis focuses on the text structure and language on modeling stages of the implementation of genre - based writing instruction model in writing class;

$\mathrm{k}$. It is able to make students carry out on exercises which manipulate relevant language forms on joints negotiation of text stages of the implementation of genre - based writing instruction model in writing class;

1. It is able to ask students to produce actual texts through activities such as choosing a topic, researching, and writing on independent construction of text stages of the implementation of genre - based writing instruction model in writing class;

$\mathrm{m}$. It is able to make students more effective to advance writing skills;

n. It is able to make students easier to arrange your ideas in terms of both achieving their communicative goals and producing more well - organizing writing skills;

o. It is very beneficial roles in helping students to produce written work with confidence on the writing process;

p. The implementation of genre - based writing instruction able to seem to serve students as an influential tool to produce actual written texts in writing task;

q. It is able to encourage the students to participate in the world around to comprehend writing as a tool that can utilize, and to realize how manage content to promote logical organization on writing;

r. It is able to make students to become more flexible in thinking and eventually to realize how organize writing;

s. It is able to make students to release from deep anxiety about writing task. 
In applying the genre-based writing instruction in English curriculum, there are four steps that should be followed: building knowledge of field, modeling, joint construction and independent construction. In the first step, building knowledge of field, generally the students are introduced to the text should be faced, the techniques that can be used are: question and answer about the text, watching video related to the text, guessing game, and the other challenging activities.

In modeling text, the students are asked to recognize the structure of the text, the language used of the text and given the model of the text. The techniques that can be used are: listening to the videos about the text, reading a text, the students also can be challenged to describe the structure of the text.

In joint construction teacher still have a role in guiding students to make a text. The teacher can use the techniques such as brainstorming, mind mapping, discussion, etc.

The last step, independent construction, the students are asked to construct a text by themselves in order to measure how far they master the lesson. The principles in applying the genre based approach is by finding more text, the students are hoped to know more kinds of text, they find more knowledge and they are able to enlarge their vocabularies. In learning English, the techniques should be developed as interesting and challenging as possible in order to make students interested and they are hoped to catch the lesson easily.

In order to be able to help students learn of writing skill based on genre - based writing instruction in learning process well, the English teachers have to manage the teaching strategies in the learning process

\section{The Relationship between Communicative Competences with Genre}

Genre is a term used to classify types of spoken or written discourse. These are normally classified by content, language, purpose and form. This theory addresses the relationship between language and its social functions and sets out to show how language is a system from which users make choices to express meanings. It advances that the context of situation of a language event on how we use language is further divided into: field (topic or focus of the activity), tenor (the relationship between the writer and reader or the speaker and hearer), and mode (expectations for how particular text types should be organized). These three components are realized through elements in the lexico-grammatical system (Martin, 1984; Halliday \& Matthiessen, 2004). That is, the way people make meaning by choosing linguistic choices varies according to the field, tenor, and mode variables that constitute the context of situation. In addition to Celce-Murcia et al. (1995) further divides communicative competence into linguistic, sociocultural, strategic, discourse and actional competencies.

In analyzing these components they start with the core, that is to say, discourse competence, which concerns the selection and sequencing of sentences to achieve a unified spoken or written text. This competence is placed in a position where linguistic, sociocultural and actional competencies shape discourse competence, which in turn, also shapes each of the three components. Linguistic competence entails the basic elements of communication, such as sentence patterns, morphological inflections, phonological and orthographic systems, as well as lexical resources. Sociocultural competence refers to the speaker's knowledge of how to express appropriate messages within the social and cultural context of communication in which they are produced. Actional competence involves the understanding of the speakers ${ }^{\text {ee }}$ communicative intent by performing and interpreting speech act sets. Finally, these four components are influenced by strategic competence, which is concerned with the knowledge of communication strategies and how to use them.

\section{Genre -Based writing Instruction}

1. The concept of writing skill

It can be said that writing is a crucial part in our global society. Writing has many general concepts. There are several definitions of writing that can be stated as follows: Among the four skills (listening, speaking, reading and writing), writing is often considered as the most difficult skill because it combines the thought and activity. This activity needs a process. According to Hedge (2000:302) states that writing is the result of employing strategies to manage the composing process, which is one gradually developing a text. It can be said that one is writing if he employs three major aspects conceived in writing (the employment of grammatical rules of the language, the employment of appropriate lexical items, and the employment of the rhetorical patterns of writing) at once.

Dealing with the employment of the grammatical rules of the language used in writing activity, one should have such a grammatical competence to deal with writing itself in order to express his ideas into an obvious meaning. Pertaining to the complexities of writing, it involves a number of activities: setting goal, generating ideas, organizing information, selecting appropriate language, making a draft, reading and reviewing it, then revising and editing. In relation the theory the writer can conclude that writing is a complex process which is neither easy nor spontaneous for many second languages.

\section{The definition of Genre}

The term genre was firstly introduced by Elaine Tarone in 1981. It has been applied in three areas of studies i.e. ESP 
(English for Specific Purpose), new rhetoric and (Systemic Functional Grammar). Genre in Language teaching is closely related to SPL area in area in which this theory describes language in terms of the choices a speaker or writer makes from the system in particular contexts of use (Paltridge, 2001: 6). In language teaching, genre derived from the Australian elementary-school classroom. In Indonesia, genre is used since curriculum in 2006 and continued on new curriculum in 2013.

In addition to, Swales (1990: 58) identified a genre as "a class of communicative events, the members of which share some set of communicative purposes". His definition offers the basic idea that there are certain conventions or rules which are generally associated with a writer"s purpose. For example, personal letters tell us about their writers"e private stories, film reviews analyze movies for potential viewers and police reports describe what happened. Most genres use conventions related to communicative purposes; a personal letter starts with a cordial question in a friendly mood because its purpose is to maintain good relationships with friends, and an argument essay emphasizes it" $\mathrm{s}$ thesis since it aims at making an argument.

\section{Types of Genre}

Biber (1988) stated that the term, genre categorizes texts on the basis of external criteria. Thus, the term ,genre describes types of activities such as, for example, prayers, sermons, songs, and poems, ,which regularly occur in society"e (Dudley-Evans 1998: 77), and, are considered by the speech community as being of the same type (Richards et al. 1992:156). Furthermore, Biber finds that the same genre can differ greatly in its linguistic characteristics. He also observed that different genres can be quite similar linguistically.

In addition to, Gerot and wignell (1995) compile kinds of genre in a different form namely, exposition (analytical), anecdote, report, exposition, narrative, discussion, new item, procedure, explanation, and review description. They then divide those text types into technical and humanities. The technical genres are such as argument; metalwork, report; and so on which related to technical work or workshop. The humanities genres are like narrative, biography, historical recount, report/descriptive, factorial explanation and argument. The following are the characteristics of each genre (Gerot and wignell, 1995)

a. Narrative

The social function of this text to amuse, entertain and to deal with actual or vicarious experience in different ways or as a reconstruction of event (Gerot and wignell, 1995). The language features of the text are:

1) It has a narrative which consists of orientation, complication, resolution structure.

2) It is sequence in time which talks about the order of the text is driven by the order of event in the world.

3) It uses past tense.

4) The focus is on participant (what they did and what happened to them) and it uses specific reference.

b. Biographical recount

This text has a similar function to the narrative except that it deal with edited highlights of event from a person's life rather than one set of event. It is a secondary or tertiary source of information. The language features of this text is it uses past tense, it is set rather than sequenced in time (through circumstances). The text focuses on an individual, specific reference.

\section{c. Historical Recount}

This text has function of constructing history; it represents a shift from an individual focus into making experience collective. The text language features is set in time and sequenced through circumstances. It is in the past tense and focuses on collective participants. There is specific reference and a balance between event and participant focus.

\section{d. Factual Report}

This text represents a further step in making experience collective; its function is to construct history. The focus shifts away from individual people to generic classes of people, doing generic things with generic artifact. The linguistic features of this text are the text has an event or activity focuses, there is a shift to predominantly simple past tense. There are generic participants and reference.

\section{e. Descriptive}

This genre is aimed at describing a particular person, place thing. The generic structures are only marked by two ways, namely identification (identifies phenomenon to be described) and description (describe parts, qualities, characteristics). The linguistic features are marked by finding specific participant, using attributive and identifying processes, using of frequent epithets and classifiers in nominal groups and using simple present tense.

f. Argumentation 
This text represents the interpretive end of the mode scale. Its function is to present reasons, supported by evidence, as to why things happened as they did. The logical structure is text driven: the argument rather than the event drives the text. The text uses interesting tense shifts, simple present tense when it is generalizing and past tense when referring to past event for exemplification. The text contains extensive nominalization and abstraction and has both generic and specific reverence.

\section{The Implementation of genre-based instruction to teaching writing}

When it comes to explaining writing development in the genre approach, Hammond at al (1992 : 202) proposed "a wheel model of a teaching learning cycle having three phases: modeling, joint negotiation of text by learners and teacher, and the independent construction of texts by learners". Modeling, Hammond noted, is the time when the target genre that students should construct is introduced to the students. At this stage, discussion focuses on the educational and social function of the genre, and analysis focuses on the text structure and language. Joint negotiation of text refers to the stage when learners carry out exercises which manipulate relevant language forms. It fosters a negotiating process between the teacher and the students. It involves reading, research, and disseminating information, and the text of the genre is dependent on those activities. The independent construction of texts is the final phase; in which learners produce actual texts through activities such as choosing a topic, researching, and writing.

The discourse genre - based approach to teaching writing focuses, as the terms suggests, on teaching particular genres that students need control of in order to succeed in particular settings. This might include a focus on language and discourse features of the texts, as well as the context in which the text is produced (Paltridge, 2002).

Then, since the mid-1980s, considerable attention has been paid to the genre approach to teaching writing. In terms of writing in a second language, The Routledge Encyclopedia of Language Teaching and Learning has defined the genre approach as "a framework for language instruction" Byram, (2004:234-237) based on examples of a particular genre. The genre framework supports students ${ }^{\text {ee }}$ writing with generalized, systematic guiding principles about how to produce meaningful passages. In the genre approach, the knowledge of language is intimately attached to a social purpose, and more focus is on the viewpoint of the reader than on that of the writer. Writing is mostly viewed as the studentse reproduction of text based on the genre offered by the teacher. It is also believed that learning takes place through imitation and exploration of different kinds of models. Accordingly, learners should be exposed to many examples of the same genre to develop their ability to write a particular genre. Through exposure to similar texts, students can detect the specialized configurations of that genre, and they also can activate their memories of prior reading or writing experiences whenever they encounter the task of creating a new piece in a familiar genre Badger \& White (2000:155-156).

\section{METHODS}

The research was conducted at senior high school that had implemented 2013 curriculum of Pesisir Selatan Regency. The data carried out 11 months from February until December 2017; they are the school year 2016/2017 of second semester (January - June 2017) and the school year 2017/2018 of the first semester (July - December 2017). The finding was in relation to the research questions about how do the English teachers manage the teaching strategies of genre- based writing instruction in learning process on senior high school students in 2013 curriculum of Pesisir Selatan Regency. This research is a qualitative evaluation. To gain the data, the researcher did some activities; firstly she observed on what happen in the classrooms were supported by checklist observation and videotaping that had provided rich data. Then she interviewed ten informants as English teachers from six senior high schools that had implemented the 2013 curriculum. These interviews that were supported by interview guide and field notes were done on different days, after interviewing the English teachers, the researcher also interviewed some students and two English supervisors to gain the valid data.

A qualitative evaluation research consists of some steps. The first is collecting the data. After the data have collected, it is analyzed. Next, the unimportant data is reduced. The data that is important is presented in the form of narration. The last is that the researcher has to draw conclusion based on the data obtained.

\section{FINDING AND DISCUSSION}

Based on the research that has been conducted at senior high school that had implemented 2013 curriculum of Pesisir Selatan Regency. Based on the researcheres observation, she found that the English teachers ${ }^{\text {ee }}$ management for the teaching strategies in learning process to help students learn English writing skill as suggested by genre-based curriculum in the classroom from ten informants of six senior high schools in Pesisir Selatan Regency hadn 't been optimally.

The first stage, building knowledge of field stages (BKOF). It showed that there are ten English teachers as informants of this research, nevertheless only two informants that manage BKOF stage; (1) give brainstorming or build up a 
shared experience and cultural context about the topic to know background knowledge of students relate about the topic. The topic should be related to the students" real life, (2) present the context through pictures, audio-visual material, excursion, field trips, guest speakers; (3) introduce the social context of the text type. The teacher can discuss with the students what they have known about the topic to activate their background knowledge and (4) having discussing and surveying with the students to establish the social purpose of text.

Next stage is modeling of text (MOT), all informants conduct this stages in MOT; (1) the teacher gives the model of the text type. This model can be given in the form of copy of real text or through the text book available. Here, the teacher asks the students to analyze the rhetorical staging or organization text on written text; (2) the teacher explain what are requirements to write this kind of text begin with the characteristics, function and grammatical used ( structure and language) and Nevertheless, only three informants conducted comparing the model with other examples of the text type. This is done to make the students understand the text type more deeply. Whereas, the other seven informants didn't do comparing the model text with other examples of the text type in making the students understand the text type more deeply, they only give explanation as a glance about the definition on the text, the communicative of the text, the language of the text and generic structure of the text.

And then, in joint construction of the text stage (JCOT), there are three informants conducted this JCOT stages; (1) the teacher asks the students to works together with students to construct texts that are similar to the texts that have learnt in the previous stage; (2) the teacher asks the students to construct their own text (joint construction of the text). Here, the teacher helps the learner by giving the skeleton text. The teacher may give question, do discussion and do edition to the students ${ }^{\text {ee }}$ construction. Remember it is done together in the class. Some students give their contribution to the construction; (3) the teacher asks the students to discuss in group.

Finally, independent construction of the text stage (ICOT), based on the researcher"s observation, all of the ten informant managed this last stages; (1) the teacher asks the students to work independently to produce their own text within the chosen genre. In this stage, the teacher will gradually reduce the contribution. While the students are writing, the teacher monitors and observes any activities in the class. On the other hand, the informants didn't have discussion about the students "work, didn "t give comment and suggestion in any necessary point and didn't revising or editing the students " construction before handing it to the teacher but the teacher collected and evaluated the students" work directly.

Next, the result of interviews of the ten informants who didn't conducted some stages in the learning process. They said that they don't understand how to help students learn English writing skill as suggested by genre-based curriculum that had implemented the 2013 curriculum. They said that they generally conducted the learning process to help students learn English writing skill by giving the students some topics and asked the students directly to write.

Generally, the researcher didn't found the step building knowledge of the text (BKOF). It was caused by the most of informants did have teaching aids or media to give brainstorming or build up a shared experience and cultural context about the topic to know background knowledge of the students relate about the topic. More ever, the students directly were introduced with the social context of the text type without discussing with the students what they have known about the topic in activating their background knowledge. In short, most of English teachers directly explained about the social purpose, text organization and linguistic feature of the text.

Next, the researcher also didn't find some activities was done by the most of informants on the JCOT stage in the teaching and learning process to manage the teaching strategies to help students learn writing skill as suggested by genre-based curriculum. It was caused by the informant directly asked the students to write because most of the informant didn't facilitate the students to create a text in group. Then, they also didn't ask each group to present the groups ${ }^{\text {"e }}$ discussion result in front the class. The researcher found that they directly to conduct on the ICOT stage by asking the students to write individually.

\section{CONCLUSION}

It seems to the researcher that the eight informants hadn't managed the teaching strategies in learning process to help student learn writing skill as suggested by genre-based curriculum in four stages; BKOF, MOT, JCOT and ICOT. Nevertheless, the eight informants only conducted two stages they are MOT and (ICOT) stages. The informants didn't conduct in learning process of writing skill about teaching strategies of Building Knowledge of Text (BKOF) and Joint Construction of text (JCOT). It was caused by limited to the teachers" knowledge and understanding to the implementation of genre - based instruction. Whereas, two informants have managed the teaching strategies in engaging genre - based writing instructions to help student learn writing skill as suggested by genre-based curriculum optimally. It was proved that two informants has conducted the four stages of the teaching strategies in learning process to help student learn writing skill as suggested by genre-based curriculum. It can be suggested that he English teachers should understand how to help students learn English writing skill as suggested by genre-based writing instruction that had implemented the 2013 curriculum. So that, 
the English teachers will be able to manage the teaching strategies in learning process to help students learn English writing skill as suggested by genre-based curriculum.

\section{References}

Byram, M. (2004). Genre and genre-based teaching. The Routledge Encyclopedia of Language Teaching and Learning (pp. 234-237). London: Routledge.

Celce-Murcia, M., Z. Dornyei, S. Thurrell 1995. Communicative Competence: A Pedagogically Motivated Model with Content Specifications. In Issues in Applied Linguistics, 6/2, pp 5-35. Retrieved from http://escholarship.ucop.edu/uc/item/2928w4zj\#page-1, on April, $7^{\text {th }} 2012$.

Dudley - Evans and John (1998). English for Specific Purpose: International in Scope, Specific in Purpose. English for Specific Purpose. 17. 115-132.

Gerot, L. \& Widnell, Peter. (1995). Making Sense of functional Grammar. Sydney: antipodean Educational Enterprises.

Hegde, T. (2000). Teaching and Learning in the Language Classroom. New York: Oxford University Press.

Hammond, J, A. Burns, H. Joyce, D. Brosnan, L. Gerot. (1992). English for Special Purposes: A handbook for teachers of adult literacy. Sydney: NCELTR, Macquarie University.

Henry, A., \& Roseberry, R. L. (1998). An evaluation of a genre-based approach to the teaching of EAP/ESP writing. TESOL Quarterly, 32(1), 154-155.

Kay, H., \& Dudley-Evans, T. (1998). Genre: What teachers think (Electronic version). ELT Journal, 52(4), 310.

Paltridge, B. (2001). Genre and the language learning classroom. Ann Arbor: University of Michigan Press.

Paltridge, B. (2002). Genre, text type, and the English for Academic Purposes (EAP). In A. M. Johns (Ed.), Genre in the classroom: multiple perspectives. Mahwah, N.J: L. Erlbaum. pp. 73-90.

Richards, J. C., \& Renandya, W. A. (2002). Teaching writing. In J. C. Richards \& W. A. Renandya (Eds.), Methodology in language teaching: An anthology of current practice (pp. 303-305). Cambridge, England: Cambridge University Press.

Richards, J. C., \& Renandya, W. A. (1992). Methodology in teaching and Anthology of Current Practice. London. Cambridge University Press.

Swales, J. M. (1990). Genre analysis: English in academic and research settings. Cambridge, UK: Cambridge University Press. 